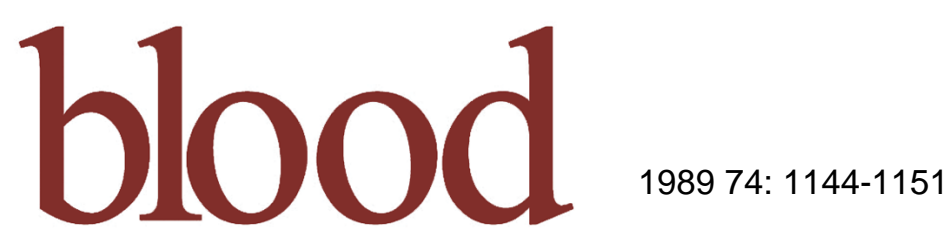

\title{
Improved hematopoiesis in anemic SI/SId mice by splenectomy and therapeutic transplantation of a hematopoietic microenvironment
}

P Anklesaria, TJ FitzGerald, K Kase, A Ohara and JS Greenberger

Information about reproducing this article in parts or in its entirety may be found online at:

http://bloodjournal.hematologylibrary.org/misc/rights.dt|\#repub_requests

Information about ordering reprints may be found online at:

http://bloodjournal.hematologylibrary.org/misc/rights.dtl\#reprints

Information about subscriptions and ASH membership may be found online at:

http://bloodjournal.hematologylibrary.org/subscriptions/index.dtl

Blood (print ISSN 0006-4971, online ISSN 1528-0020), is published semimonthly by the American Society of Hematology, 1900 M St, NW, Suite 200, Washington DC 20036.

Copyright 2007 by The American Society of Hematology; all rights reserved.

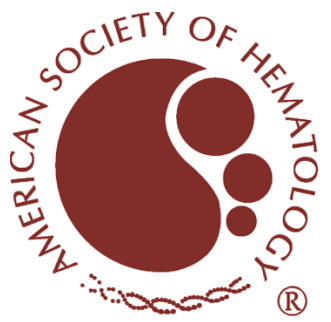




\title{
Improved Hematopoiesis in Anemic $S l / S l^{\text {d }}$ Mice by Splenectomy and Therapeutic Transplantation of a Hematopoietic Microenvironment
}

\author{
By Pervin Anklesaria, T.J. FitzGerald, Kenneth Kase, Akira Ohara, and Joel S. Greenberger
}

The ability of a clonal hematopoiesis-supportive bonemarrow stromal cell line GBIneo' to engraft and alter the microenvironment-induced anemia of $S I / S I^{d}$ mice was studied. Prior to stromal cell transplantation, $S I / S I^{d}$ mice received $1 \mathrm{~Gy}$ total body irradiation (TBI) and $13 \mathrm{~Gy}$ to the right hind limb. Two months after intravenous (IV) injection of $5 \times 10^{5}$ GBlneo' cells, $54.4 \% \pm 17.0 \%$ donor origin (G418') colony-forming cells were recovered from the right hind limb of $S I / S I^{d}$ mice. Long-term bone marrow cultures (LTBMCs) established from GBIneo'-transplanted mice produced 189.5 CFU-GEMM-forming progenitors/flask over 10 weeks compared with $52.7 \pm 6.2$ CFU-GEMM forming progenitors / flask from irradiated nontransplanted $S I / S I^{d}$ mice. A partial correction of macrocytic anemia was detected 2 months after GBIneo' transplantation in splenectomized, irradiated $\mathrm{SI} / \mathrm{S}^{\mathrm{d}}$ mice $(\mathrm{HgB} 7.2 \pm 0.4 \mathrm{~g} / \mathrm{dL}$; MCV $68.3 \pm 7.0 \mathrm{fL}$ ) compared to splenectomized, irradiated, nontransplanted $S I / S{ }^{\circ}$ mice $(\mathrm{HgB} 5.5 \pm 1.1 \mathrm{~g} / \mathrm{dL}$; MCV $76 \pm 8.5 \mathrm{fL}$ ) or control SI/S/ mice (HgB $5.4 \pm 0.5$ g/dL; MCV $82.4 \pm 1.3 \mathrm{fL}$ ). Mean RBC volume distribution

A GENETICALLY determined defect in the bonemarrow microenvironment of $S l / S l^{d}$ mice results in a deficiency of mature erythroid precursors and reduced numbers of pluripotential hematopoietic stem cells. ${ }^{1-5}$ Ultrastructural analysis of the bone-marrow of $S l / S l^{\mathrm{d}}$ mice shows a reduction in overall cellularity. ${ }^{6.7} S l / S l^{d}$ mice are not cured by allogeneic or semiallogeneic stem-cell transplantation, and spleens of irradiated mice have defective CFU-s colony formation by marrow stem cells from normal donors. ${ }^{5}$ Longterm bone marrow cultures (LTBMCs) established from $S l / S l^{\text {d }}$ mice show decreased cumulative production of hematopoietic progenitor cells compared with normal littermate mice. $^{8-11} \mathrm{X}$-irradiation of LTBMC stromal cells from $S l / S l^{\text {d }}$ mice has been shown to restore some hematopoietic support capacity. ${ }^{12}$ Recent studies with permanent clonal stromal cell lines derived from LTBMCs of $S l / S l^{d}$ mice demonstrate that some lines suppress hematopoiesis in vitro. ${ }^{9}$ The available evidence supports the conclusion that abnormal hematopoiesis observed in $S l / S l^{d}$ mice is due to a defect in cells of the hematopoietic microenvironment.

Several types of transplantation experiments have been attempted as therapy for the $S l / S l^{\text {d }}$ anemia, including parabiosis, transplantation of whole spleens, and implantation of

From Department of Radiation Oncology. University of Massachusetts Medical Center, Worcester, MA.

Submitted December 16, 1988; accepted April 19, 1989.

Supported by research grants NCI CA3985I and CA40818.

Address reprint requests to Joel $S$. Greenberger, $M D$. University of Massachusetts Medical Center, Department of Radiation Oncology. 55 Lake Ave, N. Worcester, MA 01655.

The publication costs of this article were defrayed in part by page charge payment. This article must therefore be hereby marked "advertisement" in accordance with 18 U.S.C. section 1734 solely to indicate this fact.

(c) 1989 by Grune \& Stratton. Inc.

0006-4971/89/7403-0019\$3.00/0 analysis showed a 2.5 -fold increase in percentage of peripheral blood RBCs with MCV $\leq 45 \mathrm{fL}$ and confirmed reduction of the MCV in splenectomized-GBIneo'-transplanted mice compared to control SI/SI mice. A hematopoiesis-suppressive clonal stromal cell line derived from

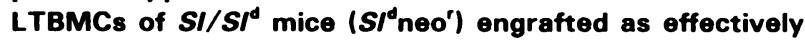
(43.5\% $\pm 1.2 \%$ G418' CFU-F/limb) as did GBIneo' cells (38.3\% $\left.\pm 0.16 \% \mathrm{G} 418^{\prime} \mathrm{CFU}-\mathrm{F} / \mathrm{limb}\right)$ to the irradiated right hind limbs of C57BI/ 6 mice. LTBMCs established after 2 or 6 months from $S I^{\text {d }}$ neo'-transplanted mice showed decreased hematopoiesis $(182 \pm 12$ [2 months] and $3494.3 \pm 408.1$ [ 6 months] CFU-GEMM forming progenitors/flask over 10 weeks) compared to those established from GBIneo'-transplanted mice $(5980 \pm 530$ [2 months] and $7728 \pm 607$, [ 6 months] CFU-GEMM progenitors forming/flask). Thus, transplantation of clonal bone-marrow stromal cell lines in vivo can stably transfer their physiologic properties to normal or mutant mice.

- 1989 by Grune \& Stratton. Inc.

normal mouse femurs into the abdominal wall. ${ }^{13-15}$ An increase in total cellularity and hematopoietic progenitors was reported in one of these studies but with no significant improvement in clinical macrocytic anemia. ${ }^{14}$ In the present studies we used a technique for bone-marrow stromal cell transplantation that involves total body irradiation (TBI) and boost irradiation to an isolated extremity followed by intravenous (IV) injection of a clonal-marrow stromal cell line. The clonal bone-marrow stromal cell line $\mathrm{GBI} / 6$ derived from LTBMCs has been shown to support hematopoietic stem cells in vitro, engrafts to targeted marrow sites, and supports hematopoietic recovery in vivo in sublethally irradiated normal mice. ${ }^{16}$ We studied the effects of transplantation of $\mathrm{GBl} / 6$ stromal cell line into $S l / S l^{\text {d }}$ recipient mice and in a reciprocal experiment the effect of transplanting a hematopoiesis-suppressive stromal cell line $\left(S !^{\text {d }} 3\right)$ derived from the $S l / S l^{\text {d }}$ mouse marrow microenvironment ${ }^{9}$ into normal mice. The data provide evidence for physiologic longterm stability and thus the therapeutic potential of marrow stromal-cell transplantation.

\section{MATERIALS AND METHODS}

Mice. Adult, 5- to 8-week-old, severely anemic WCB6F1 Sl/S $l^{\text {d }}$ mice and $\mathrm{C} 57 \mathrm{Bl} / 6$ mice were obtained from Jackson Laboratories, Bar Harbor, ME. B6'Cast'-GPI-'a' mice, obtained from Jackson Laboratories, were bred at the University of Massachusetts Medical Center.

Bone-marrow stromal cell lines. Derivation and characteriza-

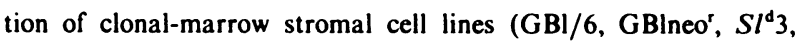
$+/+2.4$ and D2XRII) have been described previously. ${ }^{9.16,18}$ The embryo fibroblast cell line $\mathrm{Bl} / 6 \mathrm{embC}$ was provided by $\mathrm{Dr} \mathrm{S}$. Aaronson, NCI, Bethesda, MD. Neomycin (G418)-resistant subclones of $S l^{\mathrm{d}} 3$ and D2XRII and $\mathrm{Bl} / 6 \mathrm{embC}$ were established by retroviral vector-mediated gene transfer. ${ }^{17}$ The subclones are designated $S l^{\mathrm{d}}$ neo $^{r}, \mathrm{D} 2 \mathrm{Xnec}{ }^{\mathrm{r}}$, and $\mathrm{Bl} / 6 \mathrm{embneo}{ }^{\mathrm{r}} \mathrm{C}$, respectively.

Total body and hind-limb boost irradiation. Adult recipient $S l / S l^{d}$ or $\mathrm{C} 57 \mathrm{Bl} / 6$ mice received 1 to $2 \mathrm{~Gy} \mathrm{TBI}$ and 10.0 to $20.0 \mathrm{~Gy}$ 
to the right hind limb (RHL) or both hind limbs (BHL) delivered by a linear accelerator as described. ${ }^{16} \mathrm{We}$ used $1 \mathrm{~Gy} \mathrm{TBI}$ and $10 \mathrm{~Gy}$ to the RHL due to the relative sensitivity of $S l / S l^{\mathrm{d}}$ mice to TBI. ${ }^{2}$ Irradiated mice were transplanted with $5 \times 10^{5}$ stromal cells of each line (GBlneo ${ }^{r}, S l^{d}{ }^{n}{ }^{r}, \mathrm{Bl} / 6$ embneo $^{r} \mathrm{C}$ or $\left.\mathrm{D} 2 \mathrm{Xneo}{ }^{r}\right)$ by IV injection (single schedule). For sequential boost irradiation-transplantation studies with $S I / S l^{\text {d }}$ mice, $1 \mathrm{~Gy} \mathrm{TBI}$ and $10 \mathrm{~Gy}$ to the RHL was delivered by linear accelerator on day 0 . A single-cell suspension of the GBIneor cell line was injected IV 48 hours later. Two months after the first irradiation schedule, the same group of mice received 1 Gy TBI and 10 Gy to the left hind limb (LHL). Another injection of the GBlneo' cell line was administered 48 hours later (multiple transplant schedule). Control irradiated nontransplanted mice received $2 \mathrm{~Gy} \mathrm{TBI}$ and $10 \mathrm{~Gy}$ to both hind limbs (BHL).

Splenectomy and irradiation of $\mathrm{Sl} / \mathrm{SI}^{d}$ mice. SI/Sl ${ }^{\mathrm{d}}$ mice ( 5 to 6 weeks old) were anesthetized using an inhalation anesthetic methoxyflurane (metofane, Pitman Moore. Inc, Washington Crossing, NJ). A small incision was made in the flank region, and the spleen was gently removed and cauterized as described. ${ }^{14}$ The incision was sutured with a 5.0 chromic gut and the skin flaps held together with wound clips using Mikron auto clip (Clay Adams). Two weeks after splenectomy, mice were irradiated (1 Gy TBI and $10 \mathrm{~Gy}$ BHL) and transplanted (single schedule) with the GBIneo' marrow stromal cell line as described above. Transplanted and control animals were followed for clinical improvement of their sampled blood $\mathrm{HgB}$ concentration, hematocrit, and mean corpuscular volume (MCV), as described below.

Measurement of stromal cell engraftment. The CFU-F assay was carried out as described.$^{16}$ Briefly, control-irradiated-nontransplanted or irradiated-transplanted mice were sacrificed at time intervals indicated, and the harvested bone-marrow cells from each hind limb were counted and plated at different cell concentrations in 60-mm dishes (Falcon, Lincoln Park, NJ) in the absence or presence of $200 \mu \mathrm{g} / \mathrm{mL} \mathrm{G418} \mathrm{(Gibco).} \mathrm{CFU-F} \mathrm{colonies} \mathrm{(>25} \mathrm{cells)} \mathrm{were}$ counted at days 7 and 14 .

Measurement of hematopoietic recovery in vivo and in vitro. Peripheral blood from transplanted and control-irradiatednontransplanted mice was analyzed monthly. Blood from the tail vein $(80 \mu \mathrm{L})$ was collected in heparinized microhematocrit capillary tubes (Fisher Scientific, Springfield, NJ) and mixed with $20 \mathrm{~mL}$ of diluent $(\mathrm{NaCl}[6.38 \mathrm{~g} / \mathrm{L}]$, Boric acid $[1.0 \mathrm{~g} / \mathrm{L}]$, sodium tetraborate $[0.2 \mathrm{~g} / \mathrm{L}]$, and EDTA-2K $[0.2 \mathrm{~g} / \mathrm{L}])$. RBCs, WBCs, platelets, $\mathrm{HgB}$ concentration, hematocrit, and $\mathrm{MCV}$ were measured using an automated TOA-II Sysmex Counter (American Scientific Products, Stone Mountain, GA). Mean volume distribution studies of RBCs obtained from control-irradiated-splenectomized and transplanted mice were studied using a Coulter Counter with a Channalizer (Coulter, Hialeah, FL). Peripheral blood smears were made and stained with Wright's-Giemsa stain.

The functional integrity of transplanted stromal cells was evaluated by establishing LTBMCs from each hind limb as described. ${ }^{9.16}$ Hematopoietic recovery was quantitated by measuring cumulative nonadherent CFU-GEMM-forming progenitor cells removed weekly for over 10 weeks in culture. ${ }^{9.16}$

In vitro hematopoietic progenitor cell engraftment to clonal stromal cell lines. Plateau-phase cultures of each stromal cell line (GBlneor or $S l^{d}$ neo $^{r}$ ) were individually established by plating cells in $25 \mathrm{~cm}^{2}$ flasks (Corning Plastics, New York). The confluent stromal cell cultures were engrafted with 2.5 to $3.0 \times 10^{6}$ washed, nonadherent hematopoietic progenitor cells harvested from 4- to 6-week-old LTBMCs established from C57Bl/6 mice.' At weekly intervals after engraftment, nonadherent cells were harvested and assayed for CFU-GEMM-forming progenitor cells. Colony assays were performed using pokeweed-mitogen-stimulated spleen cell-conditioned medium (PWM-SCCM) and erythropoietin (EPO) as described. ${ }^{16}$
In other experiments, different ratios of the two stromal cell lines were added to same flasks to test for dominance of biologic properties.

Statistical evaluation. The differences between the means was determined by standard Student's $t$ test and chi-square analysis.'

\section{RESULTS}

Recovery of bone-marrow stromal cells in vitro after TBI and isolated hind-limb boost irradiation in vivo. The effects of TBI ( 1 to $2 \mathrm{~Gy}$ ) and high-dose irradiation to the RHL (13 Gy) on regeneration of normal C57Bl/6 and $S l / S l^{d}$ mouse-marrow stromal cells in vivo were studied first. Two days following $1 \mathrm{~Gy}$ TBI and $13 \mathrm{~Gy}$ to the RHL, the femoral CFU-F from normal C $57 \mathrm{Bl} / 6$ mice decreased to $53 \%$ of the level detected in control-nonirradiated mice (Fig 1). By 60 days after irradiation, a further decrease ( $26 \%$ of control) in the colony-forming potential of marrow stromal cells from irradiated $\mathrm{C} 57 \mathrm{Bl} / 6$ mice was observed $(P<.05)$. Improvement in the colony-forming ability of stromal cells from irradiated mice at 180 days after irradiation was not significant (Fig 1).

The number of colony-forming CFU-F progenitors/hind limb obtained from nonirradiated $S l / S l^{\mathrm{d}}$ mice was $53 \%$ lower than that of control nonirradiated $\mathrm{C} 57 \mathrm{Bl} / 6$ mice. At two

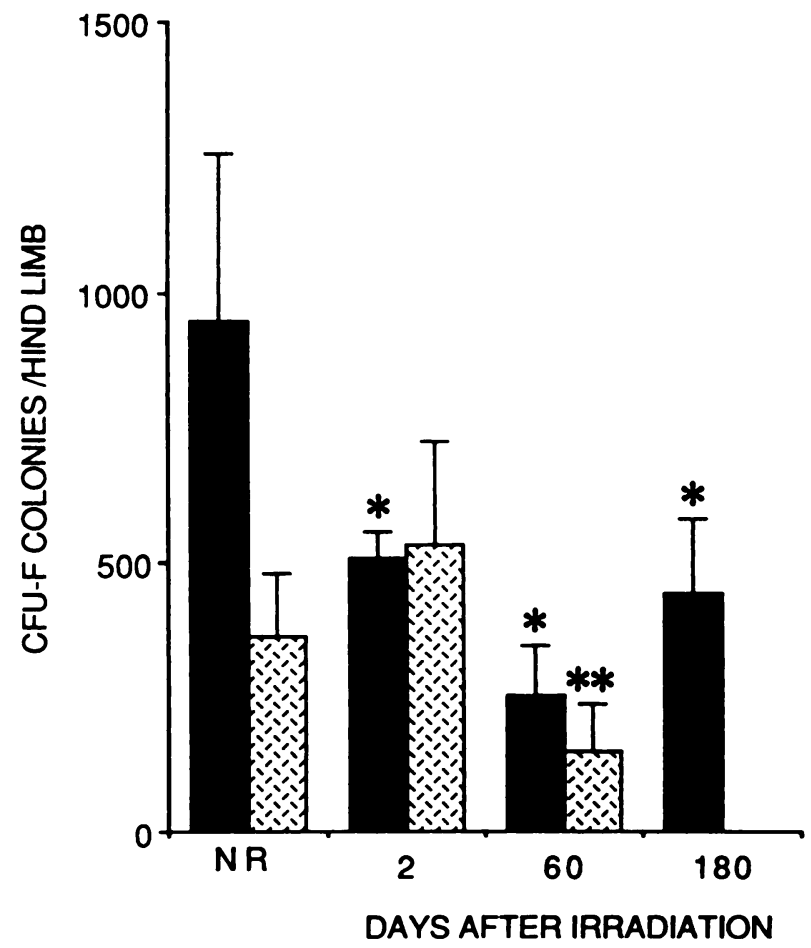

Fig 1. Stromal cell colonies (CFU-F) recovered from mice receiving TBI (1 Gy) and boost irradiation (13 Gy) to the RHL of control-nonirradiated (NR), irradiated adult C57BL/6 (D), or SI/S/ (D) mice. At time points indicated after irradiation, five mice were killed from each group. Bone marrow cells were harvested, washed, counted, and plated in duplicate at $1 \times 10^{6}$ and $5 \times 10^{6}$ cells/60-mm dish. At day 14, CFU-F colonies (>60 cells) were scored using an inverted microscope. Results are expressed as the mean \pm SD of CFU-F/hind limb. $\bullet P<.05$, compared with CFU-F from NR C57BL/ 6 mice, and $\bullet \bullet P<.05$ compared with CFU-F from NR $S I / S I^{\bullet}$ mice. 
Table 1. Support of Hematopoietic Progenitors by Stromal Cell Cultures Derived From Different Ratios of SI'neo' and GBIneo' Clonal Cell Lines

\begin{tabular}{lcc}
\multicolumn{1}{c}{ Coll Lines } & Ratio Plated & $\begin{array}{c}\text { Cumulative CFU-GEMM } \\
\text { Progenitors/Flask }\end{array}$ \\
\hline SI'neo' & 1 & $21.5 \pm 2.5$ \\
GBLneo' & 1 & $1867 \pm 218$ \\
SI'neo': GBIneo' & $1: 1$ & $33 \pm 1.8$ \\
& $1: 10$ & $584.5 \pm 8.5$ \\
& $1: 50$ & $555 \pm 43.2$ \\
SI'neo': GBIneo' & $1: 100$ & $450 \pm 79.6$ \\
\hline
\end{tabular}

- Stromal cells plated at different ratios in 25- $\mathrm{cm}^{2}$ flasks in duplicate to form confluent cultures with no further cell division possible, thus maintaining a stable ratio. Day 36 nonadherent hematopoietic cells $(3 \times$ $10^{\circ}$ cells) from C57BL/6 LTBMCs were then engrafted to each flask. At weekly intervals, nonacherent cells produced/flask were harvested and assayed for CFU-GEMM-forming progenitors.

tResults are expressed as mean \pm SD day 34 cumulative CFUGEMM-forming progenitors/flask from two separate experiments.

days after irradiation, the number of CFU-F colonies obtained from irradiated $S l / S l^{\mathrm{d}}$ mice was not significantly lower than that of control-nonirradiated $S l / S l^{d}$ mice. However, by 60 days after irradiation, there was a $41 \%$ decrease in the colony-forming ability of stromal cells from irradiated $S l / S l^{\mathrm{d}}$ mice $(P<.05$, Fig 1$)$. These data indicated that the schedule of TBI and boost irradiation would reduce the number of colony-forming host stromal cells and should provide space to support the seeding of engrafted stromal cells at this site.

Support of hematopoietic progenitor cells by stromal cell cultures derived from different ratios of $\mathrm{Sl}^{d}$ neor and $G B l n e o^{\prime}$. To estimate the number of GBlneor cells required to overcome the suppressive marrow microenvironment of $S l / S l^{d}$ mice, we first derived plateau-phase stromal cultures in vitro from different ratios of $S l^{\mathrm{d}}$ neo $^{\mathrm{r}}$ and $\mathrm{GBlneo^{r }}$ cells. These mixed stromal-cell cultures were then engrafted with day 40 hematopoietic progenitor cells from LTBMCs of Bl/6 mice. As shown in Table 1, cultures of $100 \%$ GBlneor cells supported hematopoiesis for over 4 weeks. In contrast, cultures of $100 \% S l^{d}$ neor cell line supported $1 \%$ of the number of progenitor cells compared to the GBlneor cell cultures $(P<.05)$. Plateau-phase cultures with equal numbers of GBlneor and $S l^{\text {d }}$ neor cells $(1: 1)$ supported less than $2 \%$ of the number of hematopoietic progenitors. The number of progenitors supported by stromal cultures at a 1:10 ratio of GBlneo ${ }^{r}: S l^{d}$ neo ${ }^{r}$ was $2 \%$ of the level supported by cultures of GBlneor cells $(P<.05)$. Increasing the numbers of $G B$ lneo $^{r}$ cells (tenfold, 50 -fold, or 100-fold) resulted in a $17 \%$ increase in the number of CFU-GEMM-forming progenitors supported compared to the cultures containing equal numbers of GBlneo ${ }^{r}$ and $S l^{d}$ neor cells (Table 1 ). If the results with mixed cultures in vitro were extrapolated to predict the results of engrafting new stromal cells in vivo, then up to $80 \%$ of the post-transplant hematopoietic microenvironment of $S l / S l^{d}$ mice might have to be replaced by GBlneor cells to observe a detectable biological effect.

Stromal cell line transplantation in vivo improves hematopoiesis in splenectomized $\mathrm{Sl} / \mathrm{Sl}^{d}$ mice. The ability of GBlneor cells to stably engraft into irradiated $S l / S l^{d}$ mice was first evaluated. Explanted marrow cells from controlnontransplanted mice and GBlneor-transplanted mice were selected in $200 \mu \mathrm{g} / \mathrm{mL} \mathrm{G418.} \mathrm{Two} \mathrm{months} \mathrm{after} \mathrm{transplanta-}$ tion, $54.4 \% \pm 17 \%$ of the stromal cell colonies obtained from $S l / S l^{d}$ mice transplanted with GBlneor cell line were G418 and of donor origin (Table 2, group 2). Control-irradiatednontransplanted $S l / S l^{\mathrm{d}}$ mice showed no detectable G418 adherent CFU-F (Table 2, group 4b). In comparison, the number of GBlneo ${ }^{r}$ CFU-F recovered from irradiated transplanted $\mathrm{Bl} / 6$ mice at 2 months was $38.3 \% \pm 0.16 \%$ of the total recovered from the RHL (Table 2, group 1). Thus the GBIneor cell line engrafted with equal efficiency to $S l / S l^{\text {d }}$ or C57Bl/6 mice. At 6 months after transplant, no donor origin G418 $\mathrm{CFU}-\mathrm{F}$ were detected in the RHL of $S l / S l^{\mathrm{d}}$ recipients

Table 2. Recovery of Donor Origin Cells From Hind Limb Explants of Mice Transplanted With Clonal Stromal Cell Lines

\begin{tabular}{|c|c|c|c|c|c|}
\hline \multirow[b]{3}{*}{ Group } & \multirow{2}{*}{\multicolumn{2}{|c|}{$\begin{array}{l}\text { Total No. of Stromal } \\
\text { Cell Colonies Per Hind Limb } \\
22 \mathrm{mos}\end{array}$}} & \multicolumn{3}{|c|}{$\begin{array}{l}\text { Total No. G4 18-Resistent Donor } \\
\text { Origin Stromal Cell Colonies Per Hind Limbt }\end{array}$} \\
\hline & & & \multicolumn{2}{|c|}{$2 \mathrm{mos}$} & \multirow{2}{*}{$\frac{6 \text { mos }}{\text { Right }}$} \\
\hline & Right & Left & Right & Left & \\
\hline $\begin{array}{l}\text { 1. C57B 1/6 mice trans- } \\
\text { planted with GBIneo' } 8.1 \\
\text { cells }\end{array}$ & $78.0 \pm 13.0$ & $98.7 \pm 13.3$ & $\begin{aligned} 30 & \pm 2.0 \\
(38.3 & \pm 0.16)\end{aligned}$ & $\begin{array}{l}10.3 \pm 2.0 \\
(9.9 \pm 3.0)\end{array}$ & $\begin{array}{c}17.6 \pm 16 \\
(22.5 \pm 20)\end{array}$ \\
\hline $\begin{array}{l}\text { 2. } S I / S I^{d} \text { mice transplanted } \\
\text { with GBIneo' } 8.1 \text { cells }\end{array}$ & $182.4 \pm 9.1$ & $126.0 \pm 47.0$ & $\begin{array}{c}99.3 \pm 32 \\
(54.4 \pm 17.0)\end{array}$ & $\begin{array}{c}65.0 \pm 36.0 \\
(51.6 \pm 28.0)\end{array}$ & 0 \\
\hline $\begin{array}{l}\text { 3. C57B 1/6 cells mice trans- } \\
\text { planted with } S I^{d} \text { neo' } 3.3 \\
\text { cells }\end{array}$ & $88.5 \pm 7.0$ & $90.0 \pm 20.3$ & $\begin{array}{c}38.5 \pm 8.5 \\
(43.5 \pm 1.2)\end{array}$ & $\begin{aligned} 29.5 & \pm 10.4 \\
(32.7 & \pm 1.2)\end{aligned}$ & $\begin{array}{l}7 \pm 4 \\
(8 \pm 4.5)\end{array}$ \\
\hline $\begin{array}{l}\text { 4. Control-irradiated-non- } \\
\text { transplanted }\end{array}$ & $65.5 \pm 4.1$ & $110.1 \pm 10.3$ & 0 & 0 & 0 \\
\hline $\begin{array}{l}\text { (a) (C57B } 1 / 6 \text { mice) or } \\
\text { (b) }\left(S I / S I^{d} \text { mice) }\right.\end{array}$ & $25.0 \pm 5.0$ & NT & 0 & 0 & 0 \\
\hline
\end{tabular}

Abbreviation: NT, not tested.

-The C57B $1 / 6$ mice received 3 Gy TBI and 13 Gy to the RHL; SI/SI mice received 1 Gy TBI and 11 Gy to the RHL. Results are expressed as mean \pm SD for three to five animals/group.

tThe values in parenthesis are \% of the values obtained in cultures without G418. 
(Table 2, group 2). In contrast, at 6 months, $22.5 \% \mathrm{G} 418^{\mathrm{r}}$ CFU-F colonies were still detected in GBlneor transplanted C57Bl/6 mice (Table 2, group 1).

The in vivo hematopoietic recovery of GBlneor-transplanted $S l / S l^{\mathrm{d}}$ mice was next studied. Peripheral blood counts from control-irradiated (1 Gy TBI + 10 Gy RHL)nontransplanted $S l / S l^{d}$ mice were similar to those of nonirradiated $S l / S l^{\text {d }}$ mice (Table 3, group II, III). Irradiated $S l / S l^{\text {d }}$ mice transplanted with GBlneor cells (single schedule) showed no significant recovery of the peripheral blood counts at 60 days (Table 3 , group IVa). $S l / S l^{\text {d }}$ mice receiving sequential boost irradiation of both hind limbs and multiple schedule transplants also showed no significant hematopoietic recovery in vivo at 120 days (Table 2 , group IVb).

To determine whether the failure to achieve detectable hematopoietic recovery in the GBlneo'-transplanted mice was attributable to the inability of these cells to overcome the suppressive microenvironment of the $S l / S l^{\text {d }}$ anemia, we next repeated the transplant studies in splenectomized $S l / S l^{\text {d }}$ mice. A group of $S l / S l^{\mathrm{d}}$ mice were splenectomized 15 days before TBI and hind-limb irradiation (10 Gy BHL) and were then transplanted with the GBIneor cell line. Splenectomized, irradiated, GBlneor-transplanted mice had significantly increased WBC counts and $\mathrm{Hgb}$ concentration $(9.5 \pm 1.4 \times$ $10^{3} / \mu \mathrm{L}$ and $7.2 \pm 0.4 \mathrm{~g} / \mathrm{dL}$, respectively [Table 3 , group $\mathrm{V}$ ]) at 2 months, compared with nonirradiated $S l / S l^{\mathrm{d}}$ mice (WBC counts: $4.6 \pm 0.6 \times 10^{3} / \mu \mathrm{L} ; \mathrm{Hgb}$ concentration: $5.4 \pm 0.5 \mathrm{~g} / \mathrm{dL}$, Table 3 , group III $P<.05$ ). The splenectomized GBIneo'-transplanted mice at 2 months had reduced $\operatorname{MCV}(68.3 \pm 7.0 \mathrm{fL})$ compared with that from control mice $(82.4 \pm 1.3 \mathrm{fL} ; P<.05$, Table 3 , group II). RBC volume distribution analysis demonstrated clear differences in RBC volumes comparing $S l / S l^{\mathrm{d}}$ mice to normal C57Bl/6 mice, with only a small overlap between the two populations (Fig 2). The median MCV for normal RBCs from C57Bl/6 mice was $30 \mathrm{fL}$ (range 16 to $45 \mathrm{fL}$ ) and that for $S l / S l^{\mathrm{d}}$ mice was 78 fL (range 52 to $83 \mathrm{fL}$; Fig 2). In the peripheral blood RBC population obtained from splenectomized GBIneor-transplanted $S l / S l^{\mathrm{d}}$ mice, there was a 2.5 - and 1.5 -fold increase in the percentage of cells with MCV of $45 \mathrm{fL}$ and $52 \mathrm{fL}$ respectively as compared with those obtained from $S l / S l^{\text {d }}$ mice (Fig 2). This shift in red cell volume to normal levels suggests a detectable partial correction of the macrocytic anemia in vivo in GBlneor transplanted mice.

The physiologic function of GBlneor cells in different groups of transplanted $S l / S l^{\mathrm{d}}$ mice was next evaluated by in vitro culture of marrow. The first group consisted of mice receiving 1 Gy TBI and 13 GY to the RHL. Marrow cultures established from irradiated-nontransplanted $S l / S l^{\text {d }}$ mice showed increased cumulative progenitor cell production per flask (RHL, $10 \mathrm{~Gy} ; 52 \pm 10$ progenitors/flask) compared to those from nonirradiated control mice ( $16 \pm 4$ progenitors/ flask; $P<.01$; Fig 3 ). The cumulative number of nonadherent CFU-GEMM-forming progenitors produced in LTBMCs from RHL ( $10 \mathrm{~Gy}$ ) of GBlneo' transplanted $S / / S l^{\text {d }}$ mice was 189.5 progenitors/flask. This was higher than that produced either in LTBMCs from control-nonirradiated or control-irradiated-nontransplanted mice. In contrast, LTBMCs established from the left hind limb of transplanted mice ( $1 \mathrm{~Gy}$ ) supported multipotential progenitor cell production less efficiently (46.5 CFU-GEMM forming progenitors/flask; Fig 3). In the next two groups tested, we attempted to replace a dominant fraction of the marrow microenvironment of $S l / S l^{\text {d }}$ mice by preparing the mice with either $2 \mathrm{~Gy}$ TBI and $20 \mathrm{~Gy}$ to both hind limbs (BHL, single schedule) or by sequential irradiation transplantation (multiple schedule), as described in Materials and Methods. In both experiments none of the control-irradiated-nontransplanted mice survived. LTBMCs established from GBlneortransplanted mice ( $2 \mathrm{~Gy}$ TBI and $20 \mathrm{~Gy}$ BHL) at 4 months showed increased cumulative CFU-GEMM-forming progenitors/flask in both right $(298.8 \pm 32.7)$ and left $(415.8 \pm 36.5)$ hind limb cultures compared to nonirradiated $S l / S l^{d}$ mice $(P<.05 ;$ Fig 4$)$. In separate experiments, 2 months after mice received the second irradiation transplantation, the cumulative number of CFU-GEMM-forming progenitors obtained per flask was higher in LTBMCs established from engrafted RHL $(136.1 \pm 32)$ and LHL (78.6 \pm 15.4$)$ of GBlneor-transplanted mice compared with those from control-nonirradiated $S l / S l^{\mathrm{d}}$ mice $(P<.05$; Fig

Table 3. Hematopoietic Recovery at Two Months in SI/SI Mice Transplanted With GBIneo' Cells

\begin{tabular}{|c|c|c|c|c|c|c|}
\hline \multirow[b]{2}{*}{ Group* } & \multicolumn{6}{|c|}{ Peripheral Blood Analysis } \\
\hline & $\begin{array}{c}\text { WBC } \\
\times 10^{3} / \mu \mathrm{L}\end{array}$ & $\begin{array}{c}\text { RBC } \\
\times 10^{\circ} / \mu \mathrm{L}\end{array}$ & $\begin{array}{l}P L T \\
\times 10^{3} / \mu L\end{array}$ & $\begin{array}{l}\mathrm{HgB} \\
\mathrm{g} / \mathrm{d}\end{array}$ & $\begin{array}{c}\text { HCT } \\
\%\end{array}$ & $\begin{array}{c}\text { MCV } \\
\text { (FL) }\end{array}$ \\
\hline I. Normal C57B 1/6 & $7.5 \pm 1.7$ & $8.1 \pm 0.2$ & $514 \pm 145$ & $12.1 \pm 0.4$ & $35.4 \pm 6.6$ & $36.6 \pm 4.4$ \\
\hline II. Nonirradiated $S I / S I^{d}$ & $4.6 \pm 0.67$ & $2.1 \pm 0.2$ & $234.9 \pm 70.2$ & $5.4 \pm 0.5$ & $17.5 \pm 1.2$ & $82.4 \pm 1.3$ \\
\hline $\begin{array}{l}\text { III. Irradiated-nontransplanted } S I / S I^{\alpha} \\
\text { IV. } S I / S I^{\circ} \text { transplanted with } \mathrm{GB} \mid \mathrm{n} e 0^{\prime}\end{array}$ & $4.5 \pm 0.7$ & $2.9 \pm 0.1$ & $142 \pm 5$ & $6.6 \pm 0.1$ & $20.8 \pm 0.15$ & $71 \pm 2$ \\
\hline a) At 60 days (RHL) & $4.3 \pm 0.5$ & $2.57 \pm 0.37$ & $411 \pm 200$ & $6.0 \pm 1.1$ & $18.1 \pm 3.4$ & $70 \pm 2.9$ \\
\hline b) At 120 days (BHL) $\dagger$ & $3.26 \pm 0.5$ & $1.9 \pm 0.57$ & $153.3 \pm 53$ & $4.9 \pm 1.6$ & $17.0 \pm 6.0$ & $86.6 \pm 7.5$ \\
\hline $\begin{array}{l}\text { V. } S I / S I^{d} \text { splenectomized and trans- } \\
\text { planted with GBIneo' (BHL) } \\
\text { VI. } S I / S I^{d} \text { splenectomized irradiated }\end{array}$ & $9.5 \pm 1.4 \ddagger$ & $3.15 \pm 0.2$ & $152.6 \pm 43.4$ & $7.2 \pm 0.4 \ddagger$ & $19.1 \pm 3.8$ & $68.3 \pm 7.0 \ddagger$ \\
\hline nontransplanted & $7.6 \pm 1.9$ & $2.24 \pm 0.6$ & $201.3 \pm 118.0$ & $5.5 \pm 1.1$ & $16.6 \pm 3.5$ & $76 \pm 8.5$ \\
\hline
\end{tabular}

- Results are expressed as mean \pm SD for at least three to five mice per group.

fln group (b) mice received sequential irradiation-transplantation (multiple schedule), and all control-irradiated-nontransplanted mice died within 15 days after second irradiation.

$\ddagger P<.05$ as compared to control-nontransplanted $S I / S I^{\circ}$ mice. 


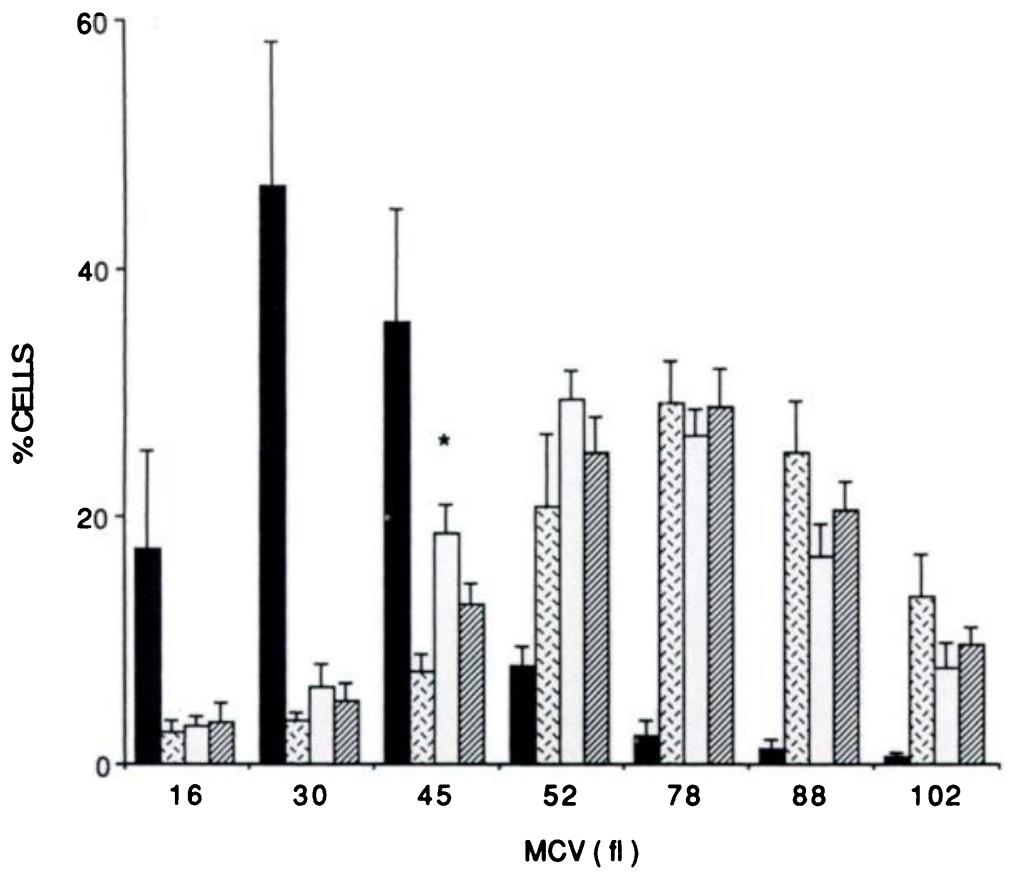

Fig 2. RBC volume distribution analysis. Peripheral blood from normal C57BL/6 (D), SI/SI (D). splenectomized GBIneo'-transplanted $S I / S I^{d}$ (D). and splenectomized-irradiated-nontransplanted $S I / S I^{d}$ (河) mice at 4 months was diluted $1: 10.000$ and run at $11 /$ amp and $1 / 21 /$ current setting of a Coulter Counter. MCV (fL) was estimated using standard latex particles (d $=3.14 \mu \mathrm{mol} / \mathrm{L}$ ). Results are expressed as mean \pm SD percentage of total cells counted. At least five mice were analyzed per group. $\bullet P .05$ compared with control $S I / S I^{d}$ mice.
4). Thus the transplanted GBlneor cells functioned both in vivo in splenectomized $S l / S l^{\mathrm{d}}$ mice to support hematopoiesis and in vitro after explant to LTBMC.

Transplantation of the $\mathrm{Sl}^{d}$ neor stromal cell line to irradiated C57BL/6 mice. Normal C57Bl/6 mice that received TBI and RHL irradiation ( $1 \mathrm{~Gy}$ TBI and $10 \mathrm{~Gy} \mathrm{RHL)} \mathrm{were}$ transplanted with the $S l^{d}$ neor stromal cell line. At 2 and 6 months after transplantation, adherent stromal cells explanted from femurs and tibias of transplanted mice were selected in $\mathrm{G} 418$, and the percentage of donor-origin stromal cells recovered was $43.5 \% \pm 1.2 \%$ and $8 \% \pm 4.5 \%$ respectively (Table 2, group 3). Thus the $S l^{\mathrm{d}}$ neo $^{\mathrm{r}}$ cell line engrafted in vivo to $\mathrm{Bl} / 6$ mice as efficiently as the Gblneor cell line (Table 2, group 1). Marrow cultures established from mice transplanted with the GBlneor stromal cell line had significantly higher CFU-GEMM-forming progenitors per flask ( 2 months $5980 \pm 530$; 6 months $7728 \pm 607, P<.05$ ) compared with those from either control-irradiated-nontransplanted or $S l^{\mathrm{d}}$ neo ${ }^{\mathrm{r}}$-transplanted mice (Fig 5). In contrast, the cumulative number of hematopoietic progenitors supported by LTBMCs established at 2 and 6 months post-transplantation from $S l^{d}$ neo $^{r}$ transplanted mice was $182 \pm 12$ and $3494 \pm 408$ CFU-GEMM progenitors/flask, respectively, and was no higher than that detected with marrow cultures
Fig 3. Hematopoiesis in LTBMCs established from hind limbs of irradiated and GBLneo'-transplanted SI/SH mice. At 2 months after transplant. LTBMCs were established from RHL and LHL of three to five mice per group of control-nonirradiated $S I / S / 4$ mice (-O-); irradiated-nontransplanted RHL-10 GY (-৩-); and LHL-1 Gy (- $\square-$ ). GBIneo' transplanted RHL-10 Gy $(-\rightarrow)$, and LHL-1 Gy (- - ). Results are expressed as mean \pm SD of cumulative CFUGEMM progenitors/flasks.

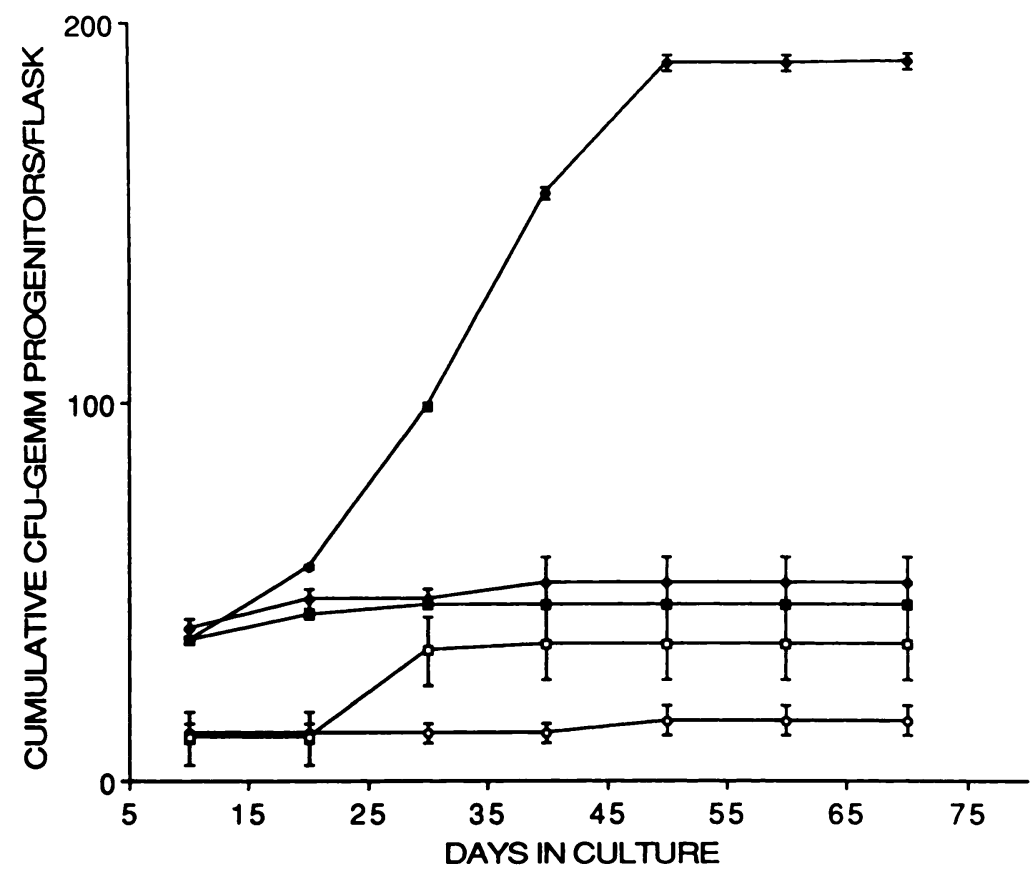


Fig 4. Support of hematopoietic progenitors harvested from LTBMCs established from $S I / S^{\circ}$ mice after 2 Gy TBI and 20 Gy to BHL (single schedule) or 1 Gy TBI and $10 \mathrm{GY} \mathrm{RHL}$ followed by a second irradiation dose of $1 \mathrm{~Gy}$ TBI and $10 \mathrm{~Gy} \mathrm{LHL}$ 2 months later (multiple transplant schedule). At 4 months after irradiation-transplantation. LTBMCs were established from three mice/group. Control. nonirradiated $S I / S I^{4}$ mice (-O-), GBIneo' transplanted RHL-20 Gy (- -$)$ ), LHL-20 GY (-口-). sequentially irradiated GBIneo'-transplanted RHL10 Gy (- -), and LHL-10 Gy (- -). Results are expressed as mean \pm SD of cumulative, nonadherent CFU-GEMM progenitors/flask.

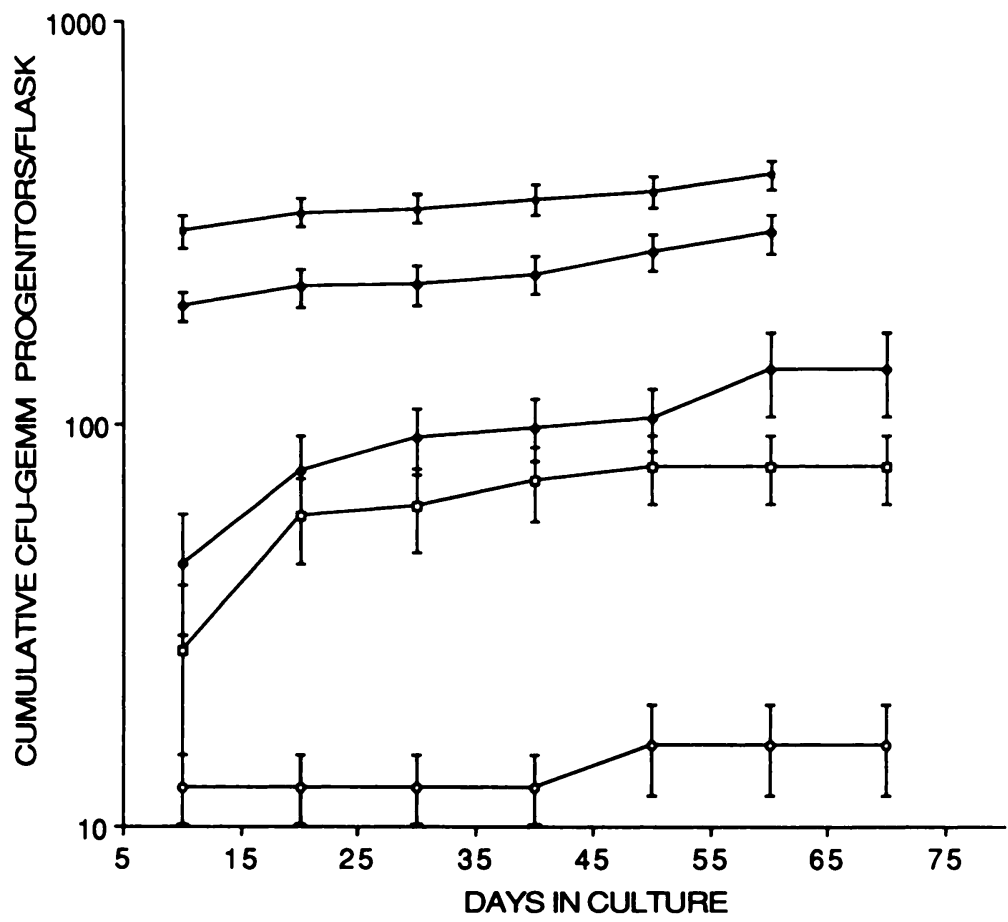

established from control-irradiated-nontransplanted mice (219 \pm 9 [2 months] and 3225 \pm 363 [6 months] CFUGEMM-forming progenitors/flask; Fig 5). Thus both the GBIneo and $S l^{d}$ neor cells transferred their in vitro biologic properties to the in vivo marrow microenvironment of $\mathrm{C} 57 \mathrm{Bl} / 6$ mice.

\section{DISCUSSION}

The present studies demonstrate that the GBIneor marrow stromal cell line engrafts in vivo and improves hematopoietic recovery in splenectomized $S l / S l^{\text {d }}$ mice. Another stromal cell line, $S l^{\mathrm{d}}$ neo $^{\mathrm{r}}$, does not support hematopoiesis in vitro but

engrafts in vivo and transfers its biologic properties to irradiated $\mathrm{C} 57 \mathrm{Bl} / 6$ mice. Thus distinct physiologic properties of two clonal stromal cell lines that are expressed in vitro are maintained following transplantation in vivo.

The engrafted GBlneor cells in splenectomized irradiated $S l / S l^{d}$ mice induced an increase in the $\mathrm{HgB}$ concentration as well as WBC counts in the peripheral blood of these mice as compared to that of control or splenectomized mice. The present data confirm and extend a previous report that demonstrated a partial stimulation of erythropoiesis in splenectomized $S l / S l^{\mathrm{d}}$ mice implanted with intact spleens from $+/+$ mice. ${ }^{14} \mathrm{~A}$ decrease in the average MCV of peripheral

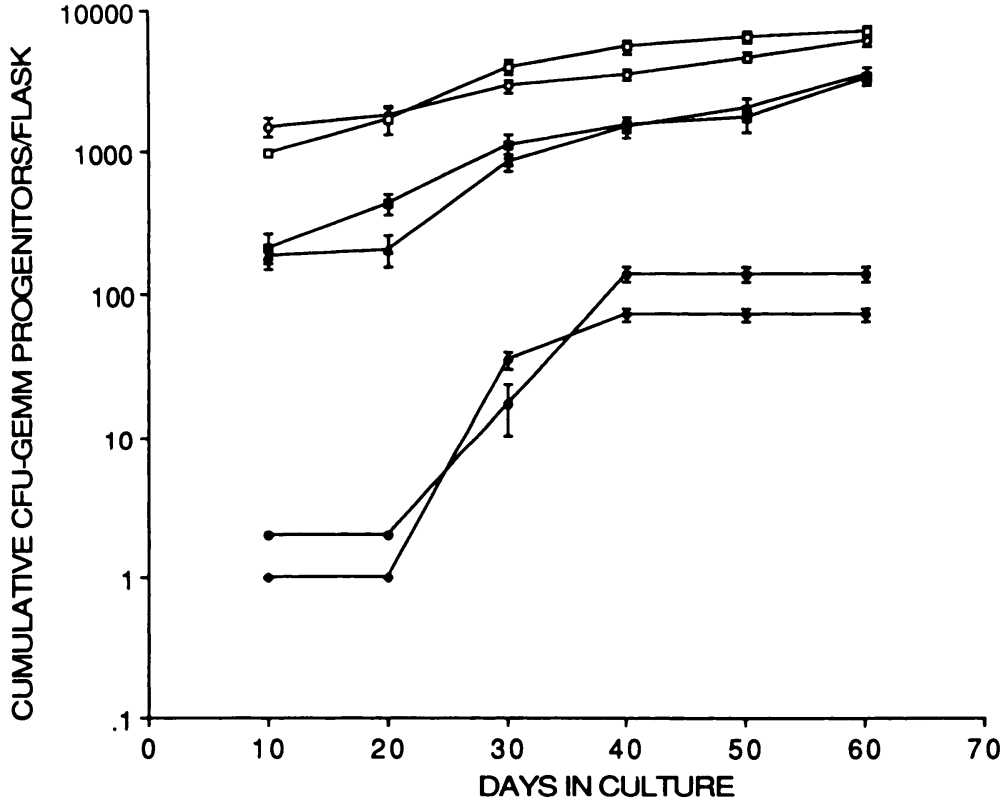

Fig 5. Hematopoietic progenitors produced in LTBMCs established from the RHLs of S/neo' and GBIneo' transplanted C57BL/6 mice. At 2 and 6 months after transplantation, three to five mice per group were sacrificed and LTBMCs established from RHL. Results are expressed as mean \pm SD cumulative, nonadherent CFU-GEMM progenitors/ flask from control-irradiated-nontransplanted mice at $2(-1-)$ and $6(-1-)$ months, from GBIneo'-transplanted mice at $2(-\mathrm{O}-)$ and 6 $(-\square-)$ months; and from $S{ }^{\circ}$ neo'-transplanted mice at $2(-\rightarrow-)$ and $6(-\Delta-)$ months. 
blood RBCs was also observed in splenectomized GBlneor transplanted mice. Furthermore, LTBMCs established at 2 and 6 months from GBlneor-transplanted $S l / S l^{\text {d }}$ mice showed increased longevity compared to marrow cultures from control $S l / S l^{d}$ mice. This may be attributable to a growth advantage in vitro of GBlneor stromal cells that further increase the favorable ratio of supportive stromal cells in vitro. LTBMCs established from control-irradiated $S l / S l^{d}$ mice supported hematopoiesis more efficiently than those from nonirradiated-control $S l / S l^{\mathrm{d}}$ mice. Thus in $S l / S l^{\mathrm{d}}$ mice, high-dose irradiation may help create a "niche" in the marrow cavity to support transplanted stromal cells and may also eliminate endogenous stromal cells that suppress hematopoiesis.

It is not yet known what characteristics are important for stable engraftment of stromal cell lines in vivo. A clonal murine embryo fibroblast $\left(\mathrm{Bl} / 6 \mathrm{embneo}^{\mathrm{r}} \mathrm{c}\right)$ and bonemarrow stromal cell line (GBlneor) that support hematopoiesis in vitro can engraft stably in vivo for up to 12 months to irradiated marrow sinuses of normal mice (unpublished observations). However, GBlneor cells were not detected by the CFU-F assay in the bone marrow of mutant $S l / S l^{d}$ mice at 6 or 12 months. One possible explanation for these data may be that the number of donor-origin cells was below the level of sensitivity of the assay used $\left(\mathrm{G} 418^{r}\right)$ for detecting donor-origin cells. Another possibility could be that either migration or regeneration of endogenous $S l / S l^{\text {d }}$ stromal cells in irradiated marrow sinuses may have eliminated or reduced the numbers GBlneor cells. Results obtained in vitro using stromal cultures made up of different ratios of $S l^{d}$ neor and
GBIneor cells indicated that one tenth the number of $S l^{d}$ neor cells could suppress support of hematopoiesis by GBlneor cells. While the $S l^{\text {d }}$ neor stromal cell line did not support hematopoiesis in vitro, it did engraft in vivo and stably transferred its suppressive microenvironment. The stromal cell line D2Xneor, which does support hematopoiesis in vitro, did not engraft in vivo (unpublished observations). Thus the parameter of in vivo engraftment of a stromal cell line does not necessarily correlate with hematopoietic support in vitro and appears to be an independent biologic marker.

The present results indicate improved hematopoiesis in anemic $S l / S l^{\text {d }}$ mice after splenectomy and engraftment of a clonal bone-marrow stromal cell line. These data support the theory that the splenic microenvironment may be involved in the pathogenesis of some types of chronic anemia. ${ }^{19-22}$ Our attempts to replace a dominant fraction of the hematopoietic microenvironment involved sequential high-dose irradiation of two marrow niches and removal of the abnormal spleen microenvironment by splenectomy. While the parameters of stromal-cell transplantation need to be optimized, the present results provide evidence that therapeutic stromal cell transplant may be a viable alternative in diseases associated with a defective marrow microenvironment. ${ }^{20-27}$

\section{ACKNOWLEDGMENT}

We are grateful to Dr S. Aaronson (NCI, Bethesda, MD) for the $\mathrm{Bl} / 6$ embryo fibroblast cell line. We thank $\mathrm{C}$. LaSalle for dedicated technical assistance and $M$. Ahlstrom and W. McNamara for preparation of the manuscript.

\section{REFERENCES}

1. Russell ES: Hereditary anemias of the mouse: A review for geneticists. Adv Genet 20:357, 1979

2. Harrison DE: Use of genetic anaemias in mice as tools for haematological research. Clin Haematol 8:239, 1979

3. McCarthy KF, Ledney GD, Mitchell R: A deficiency of hematopoietic stem cells in Steel mice. Cell Tissue Kinet 10:121, 1977

4. McCarthy, KF, MacVittie TJ: Population sizes of granulocyte-macrophage and monocyte-macrophage colony-forming cells in

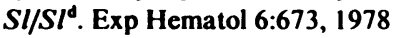

5. McCulloch EA, Siminovitch L, Till JE, Russell ES, Bernstein SE: The cellular basis of the genetically determined hemopoietic defect in anemia mice of genotype $S / / S l^{\text {d }}$. Blood 26:399, 1965

6. Shaklai M, Tavassoli M: Structural analysis of hematopoiesis in $S / / S l^{d}$ mice. Am J Pathol 90:633, 1978

7. Seed TM, Husseini SG, Knospe WH: The ultrastructure of hematopoietic stroma on cellulose after membranes implanted intraperitoneally into $S l / S l^{d}$ and $S l^{+} / S l^{+}$mice. Exp Hematol 16:705, 1988

8. Keller GM, Phillips RA: Maintenance of hemopoiesis in long-term bone marrow cultures from $S l / S l^{d}$ and $\mathbf{W} / \mathbf{W}^{\mathbf{v}}$ mice. Exp Hematol 12:822, 1984

9. Anklesaria P, Klassen V, Sakakeeny MA, FitzGerald TJ, Harrison D, Rybak E, Greenberger JS: Biological characterization of cloned permanent stromal cell lines from anemic $S l / S l^{d}$ mice and + / + littermates. Exp Hematol 15:636, 1987

10. Dexter TM: In vitro duplication and 'cure' of haemopoietic defects in genetically anaemic mice. Nature 269:412, 1977
11. Kirikae T, Yoshida M, Sawada H, Tezuka H, Kitamura Y, Mori KJ: Maintenance of granulopoiesis in long-term bone marrow cultures from $W / W^{v}$ mice and effects of lipopolysaccharide on granulopoiesis in culture. Cell Tissue Kinet 20:89, 1987

12. Zuckerman KS, Prince CW, Ribadeneira M: $S l / S l^{d}$ mouse bone marrow stroma in vitro contains an active radiation-sensitive inhibitor of normal hemopoiesis. Blood 6:1201, 1986

13. Fried W, Chamberlin W, Knospe WH, Husseini S, Trobaugh FE Jr: Studies on the defective haematopoietic microenvironment of $S l / S l^{\text {d }}$ mice. Br J Haematol 24:643, 1973

14. Berstein SE: Tissue transplantation as an analytic and therapeutic tool in hereditary anemias. Am J Surg 119:448, 1979

15. Schofield R, Lorimore SA, Wright EG: Ectopic implantation studies using $S l / S l^{\mathrm{d}}$ marrow and recipients. Exp Hematol 15:217, 1987

16. Anklesaria P, Kase K, Glowacki J, Holland CA, Sakakeeny MA, Wright JA, FitzGerald TJ, Lee C-Y, Greenberger JS: Engraftment of a clonal bone marrow stromal cell line in vivo stimulates hematopoietic recovery from total body irradiation. Proc Natl Acad Sci USA 84:7681, 1987

17. Anklesaria PN, Sakakeeny MA, Klassen V, Rothstein L, FitzGerald TJ, Greenberger JS, Holland C: Expression of a selectable gene transferred by retroviral vector to hematopoietic stem cells and stromal cells in murine continuous bone marrow cultures. Exp Hematol 15:195, 1987

18. Naparstek E, Pierce J, Metcalf D, Shadduck R, Ohle J, Leder A, Sakakeeny MA, Wagner K, Falco J, FitzGerald TJ, Greenberger JS: Induction of growth alterations in factor-dependent hemato- 
poietic progenitor cell lines by cocultivation with irradiated bone marrow stromal cell lines. Blood 67:1395, 1986

19. Heimpel H (ed): Aplastic Anemia: Pathophysiology and Approaches to Things. Berlin, Springer-Verlag, 1979

20. Camitta BM, Storb R, Thomas ED: Aplastic anemia: Pathogenesis, diagnosis, treatment and prognosis. N Engl J Med 306:645, 1982

21. Appelbaum FR, Feter A: The pathogenesis of aplastic anemia. Semin Hematol 18:291, 1981

22. Abdou NJ, Verdirame JD, Amare M, Abdou NL: Heterogeneity of pathogenetic mechanisms in aplastic anemia. Ann Intern Med 95:43, 1981

23. Roodman GD, Horadam VW, Wright TL: Inhibition of erythroid colony formation by autologous bone marrow adherent cells from patients with the anemia of chronic disease. Blood 62:406, 1983

24. Castro-Malaspina H, Gay RE, Jhanwar SC, Hamilton JA, Chiarieri DR, Meyers PA, Gay S, Moore MAS: Characteristics of bone marrow fibroblast colony-forming cells (CFU-F) and their progeny in patients with myeloproliferative disorders. Blood 59:1046, 1986

25. Ershler WB, Ross J, Finlay JL, Shahidi NT: Bone-marrow microenvironment defect in congenital hypoplastic anemia. N Engl J Med 302:1321, 1980

26. Koeffler HP: Myelodysplastic syndromes (preleukemia). Semin Hematol 23:284, 1986

27. Champlin RE, Golde DW: Chronic myelogenous leukemia: Recent advances. Blood 65:1039, 1985 